\title{
Correction to: Thanatological behavior of a female Leopard (Panthera pardus fusca)
}

\author{
Reuven Yosef ${ }^{1}$ (D) Hemant Dabi $^{2} \cdot$ Swapnil Kumbhojkar ${ }^{3}$
}

Published online: 5 April 2021

(c) ISPA, CRL 2021

Correction to: acta ethologica

https://doi.org/10.1007/s10211-021-00364-z

In the original published version of this article, the publisher regrets that the uploaded Supplementary Material was incorrect. The correct video material has been uploaded and replaces the incorrect material.

The original article has been corrected.

Publisher's Note Springer Nature remains neutral with regard to jurisdictional claims in published maps and institutional affiliations.

The original article can be found online at https://doi.org/10.1007/ s10211-021-00364-z.

Reuven Yosef

ryosef60@gmail.com

Hemant Dabi

hemantsingh740@gmail.com

Swapnil Kumbhojkar

swapnil.kumbhojkar@gmail.com

1 Ben, Gurion University of the Negev, Eilat Campus, P. O.

Box 272, 88106 Eilat, Israel

270 - A, Hathi babu Ka hatha, Polovictory Station Road, Jaipur, Rajasthan, India

3 Jhalana Wildlife Research Foundation, Jaipur, Rajasthan, India 